\title{
Novel Proton Exchange Membranes Based on Sulfonated Cellulose Acetate for Fuel Cell Applications: Preparation and Characterization
}

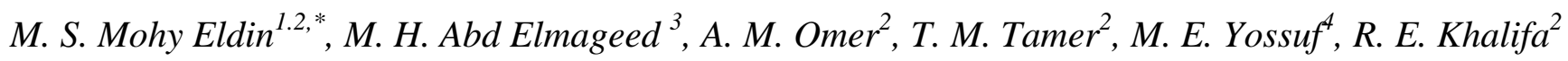 \\ ${ }^{1}$ Chemistry Department, Faculty of Science, University of Jeddah, Asfan, P. O. Box: 80203, Jeddah \\ 21589, Saudi Arabia \\ ${ }^{2}$ Polymer Materials Research Department, Advanced Technology and New Materials Research \\ Institute, MuCSAT, New Borg El-Arab City 21934, Alexandria, Egypt \\ ${ }^{3}$ Chemical Engineering Department, Faculty of Engineering, Alexandria University, Alexandria, \\ Egypt. \\ ${ }^{4}$ Computer-Based Engineering Applications Department, Informatics Research Institute, MuCSAT, \\ New Borg El-Arab City 21934, Alexandria, Egypt \\ *E-mail: m.mohyeldin@ mucsat.sci.eg
}

doi: $10.20964 / 2016.12 .18$

Received: 6 February 2016 / Accepted: 16 April 2016 / Published: 10 November 2016

\begin{abstract}
A novel sulfonated cellulose acetate (SCA) membranes synthesized for the first time as a proton exchange membrane for direct membrane fuel cells (DMFCs). Cellulose acetate was activated using epichlorohydrin $(\mathrm{ECH})$ followed by doping the activated membranes in sodium sulfite solution later on. The chemical structure and surface properties of SCA membranes confirmed by Infrared spectrophotometric analysis (FTIR). Morphological characterization was examined using scanning electron microscopy (SEM).The thermal stability of the prepared membranes tested by the thermogravimetric analysis (TGA). Results indicated that SCA membranes were thermally stable up to $375.72^{\circ} \mathrm{C}$. Interestingly, investigating essential characters required for polyelectrolyte membrane for fuel cell application show that the ion exchange capacity (IEC) estimated in the range of 0.369 $0.996 \mathrm{meq} / \mathrm{g}$ compared to $0.9 \mathrm{meq} / \mathrm{g}$ for Nafion ${ }^{\circledR} 117$. Furthermore, long membrane lifetime under oxidative conditions (Fenton's reagent), high mechanical properties $(49.25 \mathrm{~N})$, good dimensional stability, low water and methanol uptake. In addition to, lower methanol permeability $\left(1.729 * 10^{17-}\right.$ $\left.\mathrm{cm}^{2} / \mathrm{S}\right)$ compared to $\left(1.14 * 10^{9-} \mathrm{cm}^{2} / \mathrm{S}\right)$ for Nafion ${ }^{\circledR} 117$. These results make the low-cost SCA membranes a promising polyelectrolyte for direct methanol fuel cell application.
\end{abstract}

Keywords: Cellulose acetate; Proton exchange membrane; Direct methanol fuel cell; Ion exchange capacity; Methanol permeability. 
(C) 2016 The Authors. Published by ESG (www.electrochemsci.org). This article is an open access article distributed under the terms and conditions of the Creative Commons Attribution license (http://creativecommons.org/licenses/by/4.0/). 